\title{
STRATEGIES FOR REDUCING YOUTH UNEMPLOYMENT IN SOUTH AFRICA
}

\author{
Marvelous Jubane
}

University of Johannesburg, South Africa

\begin{abstract}
Youth unemployment is one of the major challenges that the majority of countries worldwide are faced with currently. In South Africa, youth unemployment has been escalating, despite the introduction of initiatives by the government to reduce unemployment. This study aims to identify the root causes of youth unemployment in South Africa and suggesting solutions to reduce youth unemployment. The researcher utilized secondary data obtained from the Quarterly Labour Force Survey by Statistics South Africa, time series data from the South African Reserve Bank and the Department of Higher Education and Training websites for conducting data analysis. The type of research methodology utilized by the research is a Quantitive research method. The findings of the study indicate that the root causes of youth unemployment include the poor education system resulting in skills mismatch in the economy. An econometric regression model was conducted by the researcher in Eviews 8 statistical data analysis software using time series data from the South African Reserve Bank, with youth unemployment being the dependent variable. The results of the econometric regression model indicated that the variables inflation rate, Gross value added a proxy for Gross Domestic Product and the Total loan debt of the nation were statistically significant at a $5 \%$ level of significance. This means that youth unemployment is influenced by the inflation rate, Gross Domestic Product and the Total loan debt of the nation or government debt. Lastly, the study discusses the recommendations to policymakers on how to reduce youth unemployment in South Africa. The results of the econometric regression indicate that youth unemployment is influenced by macroeconomic factor namely the rise in the inflation rate, decline in Gross domestic product, an increase in the government debt which deprives youth in terms government investing in youth empowerment programmes. The researcher concludes by giving policy recommendations on possible programmes that can be implemented to reduce youth unemployment.
\end{abstract}

Keywords: Youth unemployment, skills-mismatch, causes, solutions

$\begin{array}{ll}\begin{array}{l}\text { Acronyms } \\ \text { Stats SA }\end{array} & \text { Statistics South Africa } \\ \text { QLFS } & \text { Quarterly labour force survey } \\ \text { DHET } & \text { Department of Higher Education and Training } \\ \text { NDP } & \text { National Development Plan }\end{array}$

Introduction and background to the problem

Unemployment occurs when the labour resources are idle in an economy which causes a decline in the national production (Gross Domestic Product). South Africa has a high unemployment rate, affecting mainly the youth (18-35 years old). One of the reasons why youth are the most impacted by unemployment is because employers require skills that most youth lack. This results in a structural skills mismatch between the skills needed by employers and the skills supplied by the job seekers. The South African government has put in place initiatives and policies dedicated to reducing the level of unemployment, namely the National Development Plan, Employee Tax Incentive and Youth Enterprise Development Strategy (National Planning Commission 2013). Despite the development of initiatives and policies by the South African government, youth unemployment still persists to rise. The lack of employment among the youth is detrimental to their well-being and the society. Youth unemployment often results in some youth joining gangs, prostitution, drug abuse, and becoming 
involved in criminal activities for survival purposes. It is therefore imperative that youth be equipped for their future while they are still at school, through initiatives such as youth entrepreneurship, learnerships, internships and career guidance. This research will focus on the root causes of youth unemployment and the measures that can be taken to reduce youth unemployment in South Africa. Secondary data obtained from the Quarterly Labour Force Survey and the Department of Higher Education and Training will be utilized for data analysis (Stats QLFS 2018 and DHET 2016). The findings of the research will then be discussed and then recommendations and conclusions will be given by the researcher. This study will assist policymakers with possible solutions to help reduce youth unemployment in South Africa.

\section{Literature Review}

According to Reddy (2016), "the causes of unemployment include the following:

1. Structural unemployment

Structural unemployment occurs when there is a mismatch of skills in the labour market. The categories of structural unemployment include the following:

\subsection{Structural change in the economy}

This is when primary sectors like mining weaken and reduce the number of workers employed. The miners remain unemployed and cannot find employment in new industries with advanaced technology. The researcher agrees with Reddy (2016), because the economies nowadays have shifted from being driven by primary sectors which are labour intensive towards tertiary sectors which are skills intensive.

\subsection{Geographical immobility}

This is unemployment that occurs during difficult times when people migrate to other regions searching for employment opportunities. A typical example is the Gauteng province where there has been an influx of people from other provinces in search for employment and better life (Thoka and Geyer 2019).

\section{Real wage or Classical unemployment}

Real wage unemployment occurs when wages rise above the labour market equilibrium wage, for example when supply of labour is higher the demand for labour. This type of unemployment occurs when trade unions and labour organizations bargain for wage increases, which causes a decline in the demand for labour.

\section{Cyclical or Demand deficient unemployment}

Demand deficient unemployment occurs when there is a decline in Gross Domestic Product due to a recession or economic downturn".

According to Reddy (2016), "the ways to solve the unemployment problem include the following:

3.1. Government to ensure political stability.

3.2. Enhancing the quality of education for example skills training in the school curriculum.

3.3. Encouraging self-employment and entrepreneurship among the youth.

According to Graham and De Lannoy (2016), "the causes of youth unemployment include the following:

1. The evolving nature of the labour market and mismatches within the education system.

2. The structural changes in the South African economy.

3. The high demand for skilled workers.

4. The inequality in terms of access to study material in the public schooling system

5. Limited social capital and access to information to apply for job opportunities.

6. High transport costs to interview centres. 
According to Graham and De Lannoy (2016), "Solutions to youth unemployment include the following:

1. Shift employers'appointment criteria

There is a need to restructure the labour market to become more youth friendly. This can be done through hiring youth for internships, apprenticeships and learnerships in companies that will receive a subsidy from government.

An example of such an initiative is the Harambee Youth Accelerator programme that recruits youth trains them computer skills and places them in companies (Galombik 2016).

\section{2. $\quad$ Address spatial barriers to job seeking}

A transport subsidy for job seekers can be a solution for people who are geographically displaced from job opportunities.

\section{Assist with information and social networks}

Majority of youth from poor households lack access to information on job opportunities which are available in the internet, because the youth cannot afford to purchase internet data.

\section{Work with and support the youth}

High quality local based interventions that make an effort to understand the challenges of the youth and finding ways to assist the youth are vital.

According to Graham and Mlatsheni (2015), "the causes of youth unemployment include the following:

1. When youth remain unemployed for long period after completing school, which makes employers to have little confidence on the youth's capabilities.

2. Inadequate access to social and financial assets and the lack of relevant skills.

3. Lack of internet, transport money, work experience and information regarding employment opportunities make it difficult for the poor youth to enter the labour market.

According to Graham and Mlatsheni (2015), "the solutions to youth unemployment include:

1. Enhancing public employment programmes, for example the Expanded Public Works Programme.

2. Supporting youth entrepreneurship and community development.

3. Preparing the youth with skills required in the workplace while the youth are still in school.

4. Employability interventions, for example learnerships, internships and entrepreneurship programmes".

\section{Research Methodology}

The researcher utilized secondary data obtained from Stats SA quarterly labour force survey, Gross Domestic Product and the Department of Higher Education and Training. The data for employment and GDP was for the period 2012-2018, while the data for the number of graduates was for the period 2012-2016 and time series data collected from the South African Reserve Bank database was quarterly from 2008Q1 to 2018Q4. An analysis of employment by provinces in South Africa was conducted by the researcher using data from Statistics South Africa, quarterly labour force survey. The researcher utilized a Quantitative research methodology in the form of an econometric regression model for the data analysis process. The research study is quantitative in nature where the research conducted experimental data analysis matching literature findings with Statistics South Africa employment and economic growth trends with econometric regression model findings using South African Reserve Bank data. 


\section{Research objective}

The objective of the research study was to investigate the causes of youth unemployment in South Africa and give policy recommendations on how to reduce youth unemployment.

\section{Significance of the research study}

The research study is very significant because youth unemployment is a global problem which government and the private sector need to tackle to reduce poverty and income inequality in society. The research study aims to add to the body of knowledge on ways that can be utilized to reduce youth unemployment.

\section{Research Findings}

Youth unemployment in South Africa is structural (skills mismatch) and demand deficient (recessionary) in nature. "According to the Department of Government Communications newsletter issue 13 the cause of youth unemployment includes the following:

1. The legacy of apartheid and inequalities in the education system

The deliberate exclusion of black people from high-quality education, skilled occupation under apartheid contributed to high rates of unemployment today. Inadequate education and lack of productivity are costing jobs. Unemployment increases progressively with decreased educational levels and the education system is not producing the right skills for the labour market.

\section{Labour demand and supply mismatch}

Labour supply has been influenced by the increase in the number of work seekers over the years. The South African population is a young population i.e. more people enter the working age as contrasted to the number of jobs that become available in the labour market.

\section{The effects of the $2008 / 9$ global recession}

During the financial crisis many workers lost their jobs, the largest number in manufacturing. Most companies could no longer employ more people and had to reduce the workforce, contributing to the high unemployment rate.

4. Role of trade union federations in government

Higher wage demands lead to a decrease in new employment, for example youth employment.

\section{General lack of interest for entrepreneurship}

Despite various government initiatives to enhance entrepreneurship, entrepreneurial activity in South Africa is still low. For example, the percentage of young people who are entrepreneurs remains low at $6 \%$ of the total youth (18-34 years) population (DoC Tracker, 2014).

6. Slow economic growth (decline in the Gross Domestic Product)

The South African economy has been growing slowly with relatively small employment growth over the years (Department of labour, 2013). Economic growth has been too slow to create job opportunities (DTI, 2012)". 
"Youth unemployment is a result of geographical migration across provinces in South Africa, as many youths leave their hometowns in search for better opportunities in large cities like Johannesburg, Cape Town and Pretoria. It is essential that local economic development programmes be developed in remote areas of all provinces to stimulate economic growth that will result in a reduction of provincial migration. South Africa youth are unemployed, because of the structural shifts in the economy from a labour-intensive orientation towards a skills-intensive orientation. Most of the youth are low-skilled which makes them become unable to meet employers' recruitment criteria, resulting in unemployment".

\section{Findings}

\section{Labour market trends}

\section{Employment by sector analysis}

Table 2: Employment $\begin{aligned} & \text { by sector in } \\
& 2018\end{aligned}$
\begin{tabular}{|l|c|c|c|c|c|c|c|c|}
\hline $\begin{array}{c}\text { Employment by sector in South } \\
\text { Africa (both Male \& Female) }\end{array}$ & 2012 & 2013 & 2014 & 2015 & 2016 & 2017 & 2018 & Total \\
\cline { 2 - 11 } & Thousand & Thousand & Thousand & Thousand & Thousand & Thousand & Thousand & Thousand \\
\hline Agriculture & 2785 & 2960 & 2806 & 3518 & 3496 & 3370 & 3382 & 22317 \\
\hline Mining & 1502 & 1644 & 1711 & 1818 & 1777 & 1738 & 1676 & 11866 \\
\hline Manufacturing & 7266 & 7239 & 7039 & 7047 & 6767 & 7129 & 7078 & 49565 \\
\hline Utilities & 407 & 513 & 470 & 529 & 471 & 596 & 593 & 3579 \\
\hline Construction & 4363 & 4582 & 4995 & 5621 & 5724 & 5656 & 5889 & 36830 \\
\hline Trade & 12580 & 12528 & 12808 & 12645 & 12714 & 12998 & 13120 & 89393 \\
\hline Transport & 3439 & 3656 & 3727 & 3619 & 3640 & 3908 & 3936 & 25925 \\
\hline Finance & 7607 & 7980 & 8120 & 8792 & 9098 & 9609 & 9914 & 61120 \\
\hline Community and social services & 12809 & 13405 & 13973 & 14204 & 14285 & 14436 & 14777 & 97889 \\
\hline Private households & 4927 & 4943 & 4920 & 5154 & 5133 & 5213 & 5169 & 35459 \\
\hline Other & 14 & 12 & 16 & 16 & 17 & 22 & 40 & 137 \\
\hline Total & 57699 & 59462 & 60585 & 62963 & 63122 & 64675 & 65574 & 434080 \\
\hline
\end{tabular}

Source: Stats SA, QLFS Trends 2008-2018 Q4. Numbers do not add up as result of rounding.

Economic sectors that experienced an increase in employment during the period 2012 to 2018 as shown in table 2 above include the following:

1. Construction $((5889 / 4363) \wedge 1 / 7)=1 \%$

2. Trade $\left((13120 / 12580)^{\wedge} 1 / 7\right)=1 \%$

3. Finance $\left((9914 / 7607)^{\wedge} 1 / 7\right)=1 \%$

4. Transport $((3936 / 3439) \wedge 1 / 7)=1 \%$

5. Community and social services $\left((14777 / 12809)^{\wedge} 1 / 7\right)=1 \%$

6. Private households $\left((5169 / 4927)^{\wedge} 1 / 7\right)=1 \%$.

The primary sectors, Agriculture and mining experienced a decline in employment. The Utilities sector also experienced a decline in employment. The above trends in employment indicate that the South African labour market has shifted structurally from primary sectors orientation towards secondary and tertiary orientation. This structural shift in the labour market has resulted in most youth being unemployed because the growing sectors are skills intensive. The results of the research findings match with the findings of Reddy (2016), Graham and De Lannoy (2016) and Graham and Mlatsheni (2015) that there has been a structural shift in the South African economy from being driven by primary sectors which are labour intensive towards being driven Tertiary sectors which are skills intensive. 


\section{Economic growth trends}

Table 3: Gross Domestic Product 2012 -

\begin{tabular}{|c|c|c|c|c|c|c|c|c|}
\hline \multirow{2}{*}{$\begin{array}{l}\text { GDP by sector } \\
\text { South Africa }\end{array}$} & 2012 & 2013 & 2014 & 2015 & 2016 & 2017 & 2018 & Total \\
\hline & R'000 & $\mathrm{R}^{\prime} 000$ & R'000 & $\mathrm{R}^{\prime} 000$ & $\mathrm{R}^{\prime} 000$ & $\mathrm{R}^{\prime} 000$ & $R^{\prime} 000$ & $\mathrm{R}^{\prime} 000$ \\
\hline Agriculture & 68093 & 71143 & 75982 & 71515 & 64305 & 77857 & 74157 & 503054 \\
\hline Mining & 221990 & 230772 & 226791 & 234247 & 225035 & 234522 & 230514 & 1603871 \\
\hline Manufacturing & 377330 & 381173 & 382498 & 380781 & 383903 & 383189 & 386884 & 2675759 \\
\hline Electricity & 68733 & 68289 & 67622 & 66364 & 64956 & 65329 & 65932 & 467226 \\
\hline Construction & 98329 & 102818 & 106403 & 108361 & 109640 & 109008 & 107665 & 742225 \\
\hline $\begin{array}{l}\text { Wholesale, trade } \\
\text { and retail }\end{array}$ & 400938 & 408968 & 414826 & 423365 & 430406 & 429224 & 431669 & 2939395 \\
\hline Transport & 243188 & 250129 & 258906 & 262458 & 265363 & 268993 & 273193 & 1822229 \\
\hline Finance & 562042 & 576707 & 592352 & 604767 & 616301 & 628972 & 640368 & 4221509 \\
\hline \begin{tabular}{|l|} 
General \\
government
\end{tabular} & 436466 & 450348 & 464664 & 468396 & 471158 & 472497 & 478693 & 3242222 \\
\hline Personal services & 155472 & 159530 & 162367 & 163791 & 166659 & 168834 & 170530 & 1147184 \\
\hline Total & 2632583 & 2699878 & 2752410 & 2784045 & 2797727 & 2838425 & 2859605 & 19364674 \\
\hline
\end{tabular}

Source: Stats SA. GDP 2008-2018 Q4. Researcher's own calculations, converting from quarterly data to annual data.

Table 3 above depicts trends in Gross Domestic Product (GDP) by sector in South Africa from 2012 to 2018. The sectors that experienced growth in GDP include the following:

1. Finance $\left((640368 / 562042)^{\wedge} 1 / 7=1 \%\right)$.

2. General government $\left((478693 / 436466)^{\wedge} 1 / 7=1 \%\right)$.

3. Wholesale, trade and retail $\left((431669 / 400938)^{\wedge} 1 / 7=1 \%\right)$

4. Manufacturing $\left((386884 / 377330)^{\wedge} 1 / 7=1 \%\right)$.

5. Transport $\left((273193 / 243188)^{\wedge} 1 / 7=1 \%\right)$

6. Personal services $\left((170530 / 155472)^{\wedge} 1 / 7=1 \%\right)$

The trends in GDP by sector in South Africa indicate that the economy is currently being driven by secondary (Manufacturing) and tertiary sectors (Wholesale, trade and retail, Transport, Finance, General government and Personal services). This depicts the shift of the South African economy from GDP being driven by primary sectors towards Tertiary sectors. Majority of the tertiary sectors jobs require years of experience, which majority of the youth lack, inhibiting them from being absorbed into the labour market.

\section{Number of graduates in South Africa 2012-2016}

The number of graduates who have obtained their qualifications at higher institutions in South Africa has been declining during the period 2012-2016. This indicates that the majority of youth who enrolled for post-matric studies drop out of college before obtaining their qualifications. The decline in the number of graduates who obtained their qualifications filters to the increase in youth unemployment, because those youth with incomplete studies become unemployable. Table 4 below depicts the trends in the number of graduates who obtained their qualifications during the period 2012-2016 per field of study. 
Table 4: Number of graduates per field of study, 2012-2016

\begin{tabular}{|c|c|c|c|c|c|c|}
\hline Fields of study ( Top 3) & \begin{tabular}{|l|} 
Number of \\
graduates 2012
\end{tabular} & $\begin{array}{l}\text { Number of } \\
\text { graduates }\end{array}$ & $\begin{array}{l}\text { Number of } \\
\text { graduates }\end{array}$ & $\begin{array}{l}\text { Number of } \\
\text { graduates }\end{array}$ & $\begin{array}{l}\text { Number of } \\
\text { graduates } 2016\end{array}$ & Total \\
\hline \begin{tabular}{|l|} 
Mathematics \& statistics \\
\end{tabular} & & & & & & 6731 \\
\hline \begin{tabular}{|l|} 
Mathematics \\
\end{tabular} & 207 & 719 & 749 & 782 & 271 & 2729 \\
\hline Statistics & 525 & 602 & 548 & 454 & 235 & 2364 \\
\hline Applied mathematics & 762 & 229 & 261 & 243 & 144 & 1638 \\
\hline Architecture \& Built environment & & & & & & 5808 \\
\hline Building/Construction site management & 86 & 755 & 776 & 689 & 438 & 2743 \\
\hline Environmental design/Architecture & 679 & 42 & 35 & 30 & 12 & 797 \\
\hline Architectural history \& criticism & 2182 & 25 & 21 & 32 & 8 & 2267 \\
\hline \begin{tabular}{|l|} 
Languages \\
\end{tabular} & & & & & & 6642 \\
\hline English language \& literature & 302 & 858 & 803 & 948 & 152 & 3062 \\
\hline Linguistic, comparative \& related language studies & 437 & 508 & 616 & 536 & 192 & 2289 \\
\hline Isizulu language \& literature & 897 & 149 & 86 & 118 & 40 & 1290 \\
\hline Agric sciencies & & & & & & 7630 \\
\hline Agricultural business \& management & 311 & 1258 & 1151 & 806 & 389 & 3914 \\
\hline Agricultural production \& operations & 340 & 433 & 387 & 243 & 228 & 1630 \\
\hline Food science \& technology & 1114 & 297 & 326 & 277 & 73 & 2086 \\
\hline Visual \& performining arts & & & & & & 7253 \\
\hline Design \& applied arts & 511 & 798 & 820 & 570 & 198 & 2896 \\
\hline \begin{tabular}{|l|} 
Drama/ Theatre arts \\
\end{tabular} & 647 & 400 & 409 & 335 & 104 & 1895 \\
\hline Fine \& studio art & 854 & 573 & 591 & 320 & 123 & 2462 \\
\hline Physical sciences & & & & & & 12313 \\
\hline Geography \& cartography & 550 & 1076 & 1260 & 1329 & 570 & 4785 \\
\hline Chemistry & 958 & 996 & 1119 & 1063 & 512 & 4648 \\
\hline Geology \& earth sciences & 1150 & 474 & 528 & 498 & 231 & 2880 \\
\hline Communication, Journalism \& related & & & & & & 11698 \\
\hline Communication \& media studies & 455 & 1088 & 774 & 1052 & 256 & 3625 \\
\hline \begin{tabular}{|l|} 
Journalism \\
\end{tabular} & 1039 & 463 & 441 & 307 & 105 & 2356 \\
\hline Public relations \& advertising & 1120 & 1152 & 1696 & 1404 & 345 & 5717 \\
\hline \begin{tabular}{|l|} 
Psychology \\
\end{tabular} & & & & & & 13138 \\
\hline Psychology & 400 & 1763 & 2161 & 1966 & 433 & 6723 \\
\hline Industrial \& organisational psychology & 793 & 1018 & 950 & 1084 & 298 & 4143 \\
\hline Research methodology for psychology & 1650 & 278 & 172 & 152 & 20 & 2272 \\
\hline \begin{tabular}{|l|} 
Life sciences \\
\end{tabular} & & & & & & 8058 \\
\hline \begin{tabular}{|l|} 
Physiology, pathology \& related sciencies \\
\end{tabular} & 325 & 905 & 925 & 950 & 350 & 3455 \\
\hline Biochemistry, Biophysics \& molecular Biochemistry & 576 & 547 & 631 & 590 & 194 & 2538 \\
\hline Microbilogical sciences \& immunology & 931 & 297 & 340 & 402 & 95 & 2065 \\
\hline Law & & & & & & 11082 \\
\hline Private law & 504 & 1682 & 1975 & 512 & 204 & 4877 \\
\hline Perspectives on law & 726 & 443 & 538 & 302 & 296 & 2306 \\
\hline Mercantile law & 1525 & 930 & 1050 & 283 & 112 & 3899 \\
\hline Computer \& information sciences & & & & & & 13164 \\
\hline Computer \& information sciences & 360 & 1792 & 1932 & 1290 & 875 & 6249 \\
\hline Computer programming & 898 & 959 & 877 & 708 & 514 & 3955 \\
\hline Computer science & 1438 & 357 & 400 & 417 & 348 & 2960 \\
\hline Social sciences & & & & & & 16822 \\
\hline Social work & 807 & 2351 & 2555 & 301 & 54 & 6069 \\
\hline Sociology & 1263 & 1236 & 1062 & 1189 & 289 & 5039 \\
\hline Political science \& government & 1935 & 867 & 1247 & 1165 & 500 & 5714 \\
\hline Health professions \& related clinical sciences & & & & & & 11400 \\
\hline Medical \& clinical sciences & 275 & 1603 & 1669 & 559 & 149 & 4256 \\
\hline Nursing & 1321 & 1436 & 1596 & 453 & 59 & 4865 \\
\hline \begin{tabular}{|l|} 
Dentistry \\
\end{tabular} & 1591 & 261 & 311 & 100 & 17 & 2279 \\
\hline \begin{tabular}{|l|l|} 
Engineering \\
\end{tabular} & & & & & & 24680 \\
\hline Electrical, electronics \& communications engineering & 1153 & 2628 & 2949 & 1602 & 1286 & 9618 \\
\hline \begin{tabular}{|l|l|} 
Civil engineering \\
\end{tabular} & 2162 & 2456 & 2425 & 1348 & 863 & 9254 \\
\hline Chemical engineering & 2306 & 1251 & 1374 & 604 & 273 & 5808 \\
\hline Education & & & & & & 52530 \\
\hline Eduaction, general & 3888 & 9048 & 8580 & 1980 & 236 & 23732 \\
\hline Teaching education \& professional development & 3909 & 4893 & 6599 & 0 & 0 & 15401 \\
\hline Teacher education \& professional development & 7606 & 3057 & 2733 & 0 & 0 & 13397 \\
\hline Business, Economics \& management sciences & & & & & & 102853 \\
\hline Accounting \& related studies & 2497 & 11409 & 11440 & 10941 & 4573 & 40860 \\
\hline Business administration, management \& operations & 8766 & 10117 & 9953 & 9860 & 4226 & 42922 \\
\hline Marketing & 11130 & 2673 & 2496 & 2020 & 753 & 19072 \\
\hline \multirow[t]{2}{*}{\begin{tabular}{|l|} 
Total \\
\end{tabular}} & 75861 & 79151 & 82336 & 52810 & 21643 & \\
\hline & & & & & Total 2012-2016 & 311800 \\
\hline
\end{tabular}

Source: Department of Higher Education and Training website and author's own calculations 


\section{Employment by province}

The provinces that experienced the highest increase in employment during the period 2012-2018 include Gauteng, KwaZulu Natal, Western Cape, Eastern Cape, Limpopo, Mpumalanga and North West (Table 5).

Table $\begin{aligned} & \text { Ebloyment } \\
& 2018\end{aligned}$
\begin{tabular}{|l|c|c|c|c|c|c|c|c|}
\hline $\begin{array}{l}\text { Employment by } \\
\text { province South } \\
\text { Africa }\end{array}$ & 2012 & 2013 & 2014 & 2015 & 2016 & 2017 & 2018 & Total \\
\cline { 2 - 12 } & & & & & & & & \\
\hline South Africa & 136701 & 139160 & 141641 & 144139 & 146676 & 149177 & 151629 & 1009121 \\
\hline Western Cape & 16025 & 16385 & 16752 & 17126 & 17507 & 17884 & 18250 & 119929 \\
\hline Eastern Cape & 16028 & 16175 & 16308 & 16442 & 16594 & 16787 & 16986 & 115319 \\
\hline Northern Cape & 2951 & 2991 & 3031 & 3069 & 3106 & 3144 & 3180 & 21471 \\
\hline Free State & 7321 & 7373 & 7427 & 7481 & 7530 & 7557 & 7594 & 52283 \\
\hline KwaZulu Natal & 25681 & 26057 & 26431 & 26811 & 27209 & 27630 & 28060 & 187879 \\
\hline North West & 9189 & 9360 & 9535 & 9712 & 9893 & 10070 & 10245 & 68004 \\
\hline Gauteng & 35615 & 36456 & 37326 & 38210 & 39095 & 39930 & 40738 & 267371 \\
\hline Mpumalanga & 10383 & 10596 & 10812 & 11025 & 11235 & 11437 & 11627 & 77113 \\
\hline Limpopo & 13509 & 13768 & 14019 & 14264 & 14506 & 14737 & 14948 & 99752 \\
\hline Total & 273401 & 278320 & 283281 & 288278 & 293352 & 298354 & 303257 & 2018243 \\
\hline
\end{tabular}

Source: Stats SA QLFS 2008 - 2018Q4

The trends in table 5 indicate that employment opportunities are not evenly distributed among all the 9 provinces in South Africa, which exerts pressure on some provinces, therefore resulting in high unemployment in provinces like Gauteng, Western Cape, and so forth. The growth among the provinces with an increase in the employment level are as follows:

Gauteng $\left((40738 / 35615)^{\wedge} 1 / 7\right)=1 \%$

KwaZulu Natal $\left((28060 / 25681)^{\wedge} 1 / 7=1 \%\right.$

Western Cape $\left((18250 / 16025)^{\wedge} 1 / 7=1 \%\right.$

Eastern Cape $((16986 / 16028) \wedge 1 / 7=1 \%$

Limpopo $((14948 / 13509) \wedge 1 / 7=1 \%$

Mpumalanga $((11627 / 10383) \wedge 1 / 7=1 \%$

North West $\left((10245 / 9189)^{\wedge} 1 / 7=1 \%\right.$.

The results in table 5 above correlate with the findings of Reddy (2016) that most people migrate from their hometowns to other provinces like Gauteng in search of employment opportunities and better life. Table 5 shows that Gauteng employed 267371000 people in total from 2012 to 2018. Gauteng is the leading province in terms of employment creation contrasted to other provinces (Table 5). 


\section{Youth unemployment regression equation}

Regression model in Eviews

8

(a) EViews

File Edit Object View Proc Quick Options Add-ins Window Help

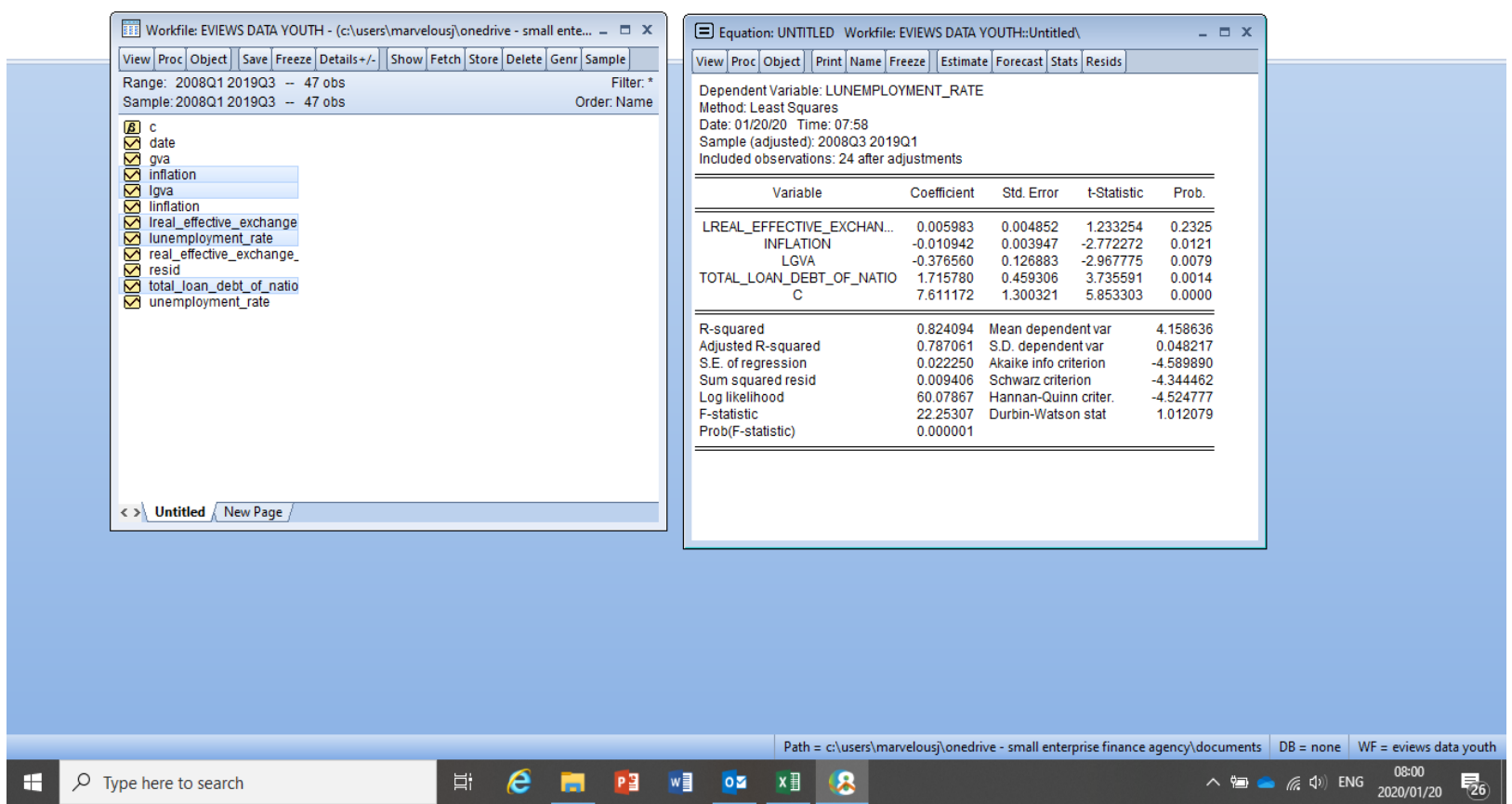

Regression equation: $\log$ (youth unemployment) $=7.6+0.006 * \log$ (Real effective exchange rate)-0.01*Inflation$0.38 * \log ($ GVA: Gross value added) $+1.7 *$ Total loan debt of nation+ error term (omitted variables).

\section{Regression output results explanation:}

A $1 \%$ change in the Real effective exchange rate will result in a $0.006 \%$ increase in youth unemployment, ceteris paribus (holding other variables constant).

A $1 \%$ change in the inflation rate will result in a $0.01 \%$ decline in youth unemployment, ceteris paribus.

A 1 unit change in the Gross value added (proxy of Gross Domestic Product) will result in a 0.38 unit decline in youth unemployment, ceteris paribus.

A $1 \%$ change in the Total loan debt of the nation (government debt) will result in a $1.7 \%$ increase in youth unemployment.

\section{Statistical significance and adjusted R-square of the model:}

The probability of the F-statistics is 0.000001 which is less than 0.05 , meaning that the model is overall statistically significant (rule of thumb: at $5 \%$ level of significance, p-value should be less than 0.05).

The p-value for Real effective exchange rate is 0.23 which is greater than 0.05 , meaning that Real effective exchange rate is statistically insignificant in explaining variability in youth unemployment.

The p-value for Inflation rate is 0.0121 which is less than 0.05 , meaning that Inflation rate is statistically significant at explaining variability in youth unemployment. 
The p-value for Gross value added (GVA) is 0.008 which is less than 0.05 , meaning that Gross value added is statistically significant at explaining variability in youth unemployment.

The p-value for Total loan debt of nation (government debt) is 0.0014 which is less than 0.05 , meaning that Total loan debt of nation is statistically significant at explaining the variability of youth unemployment.

The adjusted R-square which is a measure of goodness of fit of the model is 0.79 which is close to 1 , meaning that $79 \%$ of variability in youth unemployment is explained by the inflation rate, Gross value added (proxy for Gross Domestic Product) and the Total loan Debt of Nation (Government debt), while only $21 \%$ is explained by other omitted variables. This is a good model to explain the relationship between youth unemployment and the regressors.

\section{Conclusion and policy recommendations}

From the findings and results the researcher concludes that youth unemployment is caused by the structural shift of the economy from being driven by labour intensive sectors towards skills intensive sectors, making unskilled youth to become unemployed. Youth unemployment in South Africa is very high, which has resulted in a decline in the national Gross Domestic Product because labour resources are idle. Youth need to be encouraged to enrol and study at Technical and vocational education and training colleges that equip learners with practical skills required in the labour market and to become entrepreneurs. The results of the econometric model proved that youth unemployment is influenced by the rise in inflation rate, decline in the Gross domestic product and an increase in the government debt which deprives the nation of investments in youth empowerment programmes.

The study recommends that programmes be designed to equip the unemployed youth with the skills required by employers in the labour market. There is a need for an entrepreneurship culture to be promoted among the youth in townships and rural areas to help them become economically involved.

There is a need for more Government spending in the form of infrastructure development, to build more technical schools that will equip the youth with skills required in the labour market. Government investment programmes need to be channelled towards developing infrastructure in the rural areas, to help reduce ruralurban migration which increases unemployment in the urban areas.

Government and policy makers can use expansionary monetary and fiscal policies to tackle demand-deficient (recessionary) unemployment. Government can use supply-side policies that include entrepreneurship, internships, learnerships, apprenticeships to tackle structural (skills mismatch) unemployment.

\section{Reference}

Department of Government Communication and Information System, Republic of South Africa, 2014. Understanding the root causes of unemployment, volume 1, issue 13. Retrieved from https://www.gcis.gov.za/content/resourcecentre/newsletters/insight/issue13

Department of Higher Education and Training, Republic of South Africa. HEMIS Resources. Retrieved from https://www.dhet.gov.za/SitePages/UniversityEducation.aspx

Graham L., De Lannoy A., 2016. Youth unemployment: what can we do in the short run? December 2016. Available at http://www.econ3x3.org/article/youth-unemployment-what-can-we-do-short-run

Graham L., Mlatsheni C., 2015. Youth unemployment in South Africa. South African Child Gauge, 2015. Retrieved

from http://www.ci.uct.ac.za/sites/default/files/image tool/images/367/Child_Gauge/South_African_Child_Gauge 2 015/Child_Gauge_2015-Unemployment.pdf

Peace Child International, 2015. Youth unemployment causes and solutions, September 2015. Retrieved from https://peacechild.org/youth-unemployment-causes-and-solutions/ 
Stats SA, 2018. GDP, Annual quarterly and regional fourth quarter 2018. Retrieved from http://www.statssa.gov.za/?page_id=1854\&PPN=P0441\&SCH=7645

Stats $\quad$ SA, 2018. QLFS Trends 2008-2018 Q4. $\quad$ Retrieved from http://www.statssa.gov.za/?page_id=1854\&PPN=P0211\&SCH=7331

Reddy C., 2016. How to Solve Unemployment in a Country: Best Tips, 2016. Retrieved from https://content.wisestep.com/solve-unemployment-country-best-tips/ 